\title{
DE ACCOUNTANT EN HET ONTWERP PENSIOEN- EN SPAARFONDSENWET
}

\author{
door Lod. S. Beuth
}

Op 13 Juli 1950 werd bij de Tweede Kamer onder No. 1730 ingediend een ontwerp .,Pensioen- en Spaarfondsenwet". De verwachting is dat dit ontwerp, behoudens enige technische wijzigingen op enkele onderdelen, door beide Kamers welkom zal worden geheten, daar de strekking der wet algemeen wordt onderschreven.

In grote lijnen gaat het ontwerp uit van de constructie dat, wanneer een ondernemer, werkgever, beoefenaar van een vrij beroep, instelling of bedrijfstak, een pensioentoezegging doet of gedaan heeft, deze verplicht is ter uitvoering daarvan zich hetzij aan te sluiten bij een bedrijfspensioenfonds, hetzij een ondernemingspensioenfonds te stichten, hetzij voorzieningen te treffen of te doen treffen via de V.O.V. of een verzekeringmaatschappij (art. 2). Dit artikel bepaalt verder dat, tenzij het tegendeel uitdrukkelijk blijkt, een werkgever geacht wordt aan een persoon een toezegging te hebben gedaan, indien die persoon behoort tot een groep van werknemers, voor wie (in feite) in de onderneming een regeling betreffende pensioenen geldt. Niet van toepassing is de wet, wanneer de toezegging eerst wordt gedaan bij of nâ de opzegging van de dienstbetrekking en welke betreft de uitkering van een pensioen terstond na het eindigen van die dienstbetrekking en voorts op toezeggingen aan werknemers buiten Nederland, indien daar een voorziening werd getroffen.

In art. 7 wordt gesproken over de eisen waaraan de statuten en reglementen van een pensioenfonds moeten voldoen, terwijl art. 8 de minimumrechten vastlegt bij uittreding uit het fonds. Statuten en reglementen (en de wijzigingen hiervan) moeten door de Minister worden goedgekeurd, waardoor het fonds rechtspersoonlijkheid verkrijgt, zo het deze al niet bezat.

Art. 9 bepaalt, dat de voor ouderdoms-, weduwe- en wezenpensioenen bestemde gelden van een pensioenfonds moeten worden aangewend tot het overdragen of het herverzekeren van de uit de aangegane verplichtingen voortspruitende rechten, hetzij via de V.O.V., hetzij via pensioenen andere overeenkomsten van levensverzekering bij een levensverzekeringmaatschappij. Hieruit volgt, dat in beginsel de weg van het eigen beheer niet meer kan worden gevolgd.

Art. 10 geeft hierop de uitzondering, die door de Verzekeringskamer kan worden verleend, wanneer ten eerste het fonds werkt volgens een actuariële en bedrijfstechnische nota betreffende het te voeren beleid, waarbij de financiële opzet en de grondslagen, waarop het rust, gemotiveerd omschreven zijn en bovendien ten genoegen van de Verzekeringskamer wordt aangetoond, dat het fonds voldoende draagvlak bezit voor het zelfstandig dragen van risico. In het geval, dat deze uitzondering wordt toegestaan, verlangt de Verzekeringskamer eenmaal in de vijf jaar, of zo nodig binnen korteren termijn, een door een actuaris samengestelde wetenschappelijke balans en verlies- en winstrekening, alsmede een actuarieel verslag betreffende het fonds, terwijl jaarlijks een door een accountant gecontroleerd verslag moet worden uitgebracht, waarin een volledig beeld van de financiële toestand van het fonds wordt gegeven en waaruit ten genoegen van de Kamer blijkt, dat aan het bij of krachtens de wet bepaalde wordt voldaan en dat de belangen der bij het fonds betrokken

m a b blz. 403 
deelnemers en gewezen deelnemers voldoende gewaarborgd geacht kunnen worden. De belangrijke consequenties van dit artikel betekenen, dat het thans door de fiscus aanvaarde systeem, waarbij de accountant de berekening maakt van de verplichtingen, niet meer is toegelaten en dat men verstandig doet tijdig de mogelijkheden van risico-overdracht met een bekwaam adviseur te bespreken. Voor zover men het eigen beheer ook in de toekomst wil handhaven, is inschakeling van een actuaris voorgeschreven. Omtrent de vraag of men het eigen beheer moet voortzetten, doet men verstandig eerst een onafhankelijk deskundige te raadplegen.

Art. 12 verklaart alleen bevoegd die actuarissen en accountants, tegen wier aanwijzing of handhaving de Verzekeringskamer geen bezwaar heeft gemaakt. De Verzekeringskamer kan tegen de aanwijzing of handhaving van een actuaris of accountant slechts bezwaar maken indien de betrokkene naar haar oordeel niet of niet meer de nodige waarborgen biedt, dat hij de hem toevertrouwde taak naar behoren zal vervullen. Het bezwaar wordt schriftelijk ter kennis gebracht van het betrokken fonds en van de betrokken actuaris of accountant. Tegen een door de Verzekeringskamer uitgebracht bezwaar, kan door het bestuur van het fonds of door de actuaris of accountant, binnen een maand na de dagtekening van de kennisgeving van het bezwaar, beroep worden ingesteld bij de Minister van Sociale Zaken. Deze doet van zijn beslissing mededeling aan het fondsbestuur, aan de Verzekeringskamer en aan de betrokken actuaris of accountant.

In hoeverre deze regeling door actuarissen en accountants zal worden gewaardeerd, kan hier buiten beschouwing blijven. Dit is een interne aangelegenheid, die echter wel de aandacht van de beroepsorganen van accountants en actuarissen verdient.

Art. 13 beoogt vast te leggen dat bij de ondernemings- en bedrijfspensioenfondsen het kapitaal-dekkingstelsel moet worden gevolgd. Of de gekozen tekst de toepassing van andere ongewenste stelsels volledig uitsluit, mag worden betwijfeld. Redactionele wijziging, waarbij de tekst minder dubbelzinnig wordt, is waarschijnlijk te achten.

Art. 14 en 15 handelen over de beleggingen en bezittingen van het fonds. Zo mogen de bezittingen van een ondernemingspensioenfonds of een spaarfonds voortaan ten hoogste voor ééntiende gedeelte bestaan uit schuldvorderingen op de werkgever of aandelen van de onderneming. Een uit rekening-courant voortspruitende schuldvordering op de werkgever blijft echter tot een niet hoger bedrag dan de door de werkgever jaarlijks voor pensioenen te storten gelden bij de berekening van dit tiende gedeelte buiten beschouwing.

Van art. 13 en $15 \mathrm{mag}$ worden afgeweken, voorzover de werkgever nieuwe financiële verplichtingen boven de reeds bestaande op zich heeft genomen, doch dan moet aanpassing aan art. 13 en 15 worden nagestreefd volgens een door de Verzekeringskamer goedgekeurd plan. Hetzelfde geldt ten aanzien van een vóór de datum van de afkondiging der wet opgericht ondernemingspensioenfonds; het aanpassingsplan mag dan echter een tijdvak van 25 jaren niet te boven gaan.

De verdere bepalingen regelen het toezicht en ingrijpen van de Verzekeringskamer, vrijstellingen, strafbepalingen enz., die ik bij deze summiere beschouwing meen achterwege te mogen laten.

Deze wet zal ingrijpende gevolgen hebben voor ondernemingen die tot nog toe meenden te kunnen volstaan hutn pensioenverplichtingen balanstechnisch te kunnen dekken, ook voor zover het slechts de directiepen- 
sioenen betreft. Algehele risico-overdracht (dus niet alleen overdracht voor zover het weduwerechten betreft) aan een verzekeringmaatschappij in de vorm van polissen wordt dus norm. De polissen zullen moeten voldoen aan algemene eisen die door de Minister van Sociale Zaken, de Verzekeringskamer gehoord, nader zullen worden vastgesteld.

Het is te voorzien, dat de verzekeringmaatschappijen de door de wet gestimuleerde mogelijkheden tot uitbreiding van hun debiet, gretig zullen aangrijpen, van welke mogelijkheden het leger der veelal op dit specifieke terrein ondeskundige tussenpersonen alreeds door een massale aanval tracht te profiteren.

Worden de accountants door de nieuwe wettelijke bepalingen uitgeschakeld als "organisators" van pensioenvoorzieningen, zij houden m.i. de belangrijke taak er voor te zorgen, dat de nieuwe structuur der pensioenvoorzieningen voor hun cliënten op verantwoorde wijze wordt geregeld. 